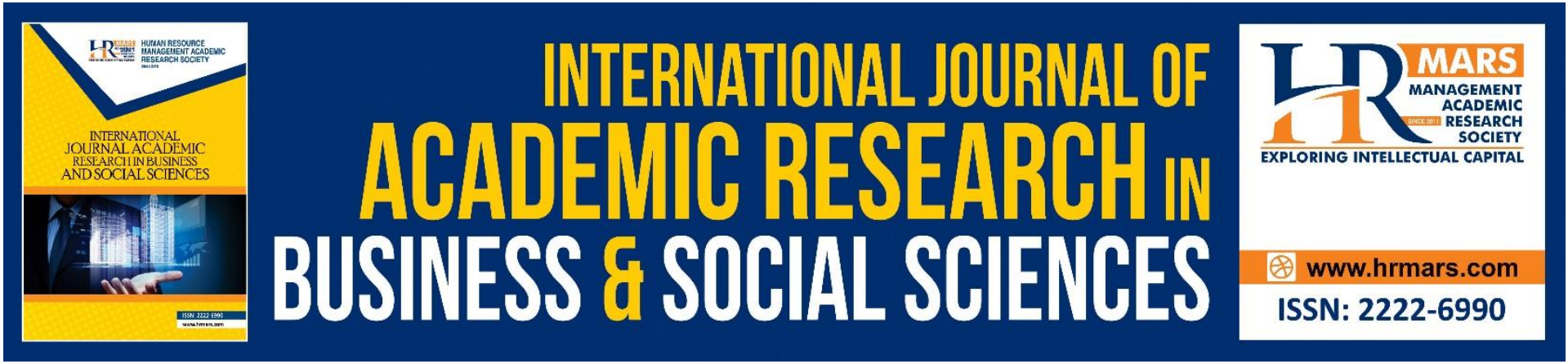

\title{
Application of Gold Dinar Waqf towards the Construction of Madani Community
}

Surita Hartini Mat Hassan, Che Khadijah Hamid, Salimah Yahaya, Sakinatul Raadiyah Abdullah, Farahdina Fazial

To Link this Article: http://dx.doi.org/10.6007/IJARBSS/v11-i4/9766

DOI:10.6007/IJARBSS/v11-i4/9766

Received: 04 February 2021, Revised: 10 March 2021, Accepted: 28 March 2021

Published Online: 29 April 2021

In-Text Citation: (Hassan et al., 2021)

To Cite this Article: Hassan, S. H. M., Hamid, C. K., Yahaya, S., Abdullah, S. R., \& Fazial, F. (2021). Application of Gold Dinar Waqf towards the Construction of Madani Community. International Journal of Academic Research in Business and Social Sciences, 11(4), 973-982.

Copyright: @ 2021 The Author(s)

Published by Human Resource Management Academic Research Society (www.hrmars.com)

This article is published under the Creative Commons Attribution (CC BY 4.0) license. Anyone may reproduce, distribute, translate and create derivative works of this article (for both commercial and non-commercial purposes), subject to full attribution to the original publication and authors. The full terms of this license may be seen at: http://creativecommons.org/licences/by/4.0/legalcode

Vol. 11, No. 4, 2021, Pg. 973 - 982

Full Terms \& Conditions of access and use can be found at http://hrmars.com/index.php/pages/detail/publication-ethics 


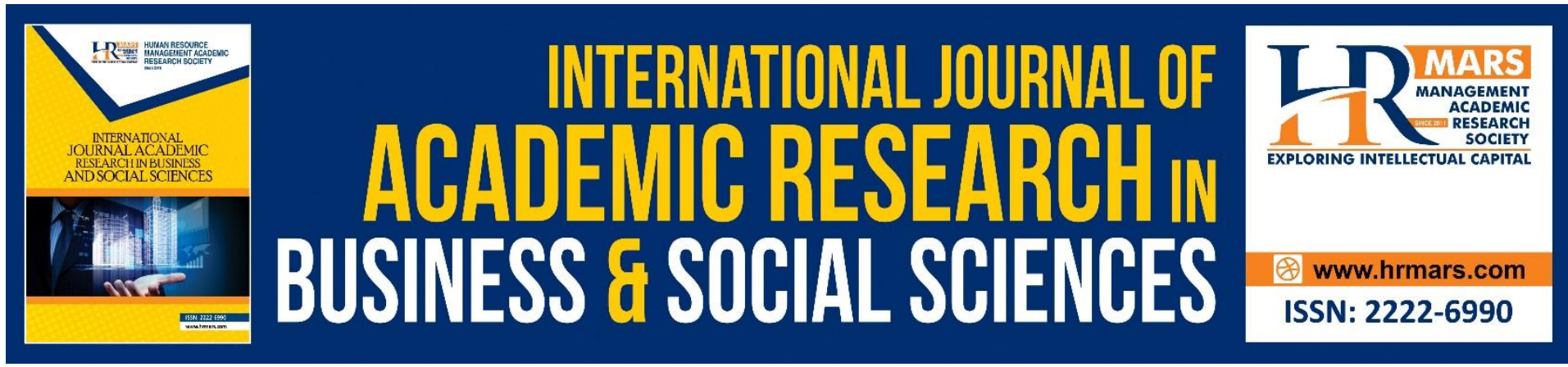

\title{
Application of Gold Dinar Waqf towards the Construction of Madani Community
}

\author{
Surita Hartini Mat Hassan \\ Universiti Teknologi MARA Cawangan Pahang, Kampus Raub, Pahang, Malaysia. \\ Email: suritahartini@uitm.edu.my
}

Che Khadijah Hamid, Salimah Yahaya

Universiti Teknologi MARA Cawangan Terengganu, Kampus Dungun, Terengganu, Malaysia.

Email: chekhadijah@uitm.edu.my, salimahyahya@uitm.edu.my

Sakinatul Raadiyah Abdullah

Universiti Teknologi MARA Cawangan Pahang, Kampus Jengka, Pahang, Malaysia.

Email: sakinatulraadiyah@uitm.edu.my

Farahdina Fazial

Universiti Teknologi MARA Cawangan Kedah, Merbok, Kedah, Malaysia.

Email: farahdinafazial@uitm.edu.my

\begin{abstract}
The excitement in ennobling gold dinar had taken place circa 1998-2002. The effort in reviving the excitement was brought back by Tun Mahathir Mohammad at the end of 2019. The question as to how effective the implementation would be, is still unanswered. This study puts forth the suggestion about the use of gold dinar as a waqf instrument better known as the waqf gold dinar (Waqaf Dinar Emas or WDE). This is because waqf is an ummah development source that has the potential in building the Madani community. The success of waqf in the ummah development is proven through the successful implementation of the waqf al-Azhar model in Egypt that has benefited the society in multiple aspects including religious, social and economic development. That said, to what extent that the WDE concept is understood? How can the use WDE be carried out? How does the WDE build the Madani community? Questions, one after another have brought forth this study aiming to identify the concept and method of implementation of the WDE and analyse its potential when it comes to constructing the Madani community. The primary data is obtained through the in-depth interview with two informants namely a waqf practitioner and an academician. The secondary data is obtained based on the study on previous works such as theses, books, articles, journals and magazines. This data is analysed qualitatively using ATLAS.ti Version 8.0 (AV8). The outcome of this study discovers four things needed in the WDE implementation namely urge from influential community, the R\&D cooperation between the research group and the parliament members, the involvement of the institution also the waqf manager and the
\end{abstract}


combination of the people in the professional field and the people in the religious field. All these four aspects can help realise the construction of the Madani community.

Keywords: Gold Dinar, Waqf, Waqf Gold Dinar, Madani Community, The Construction of The Madani Community

\section{Introduction}

Waqf is a source of the ummah development. This is evident through the success of the waqf practice during the time of Muhammad SAW and the rulers after him, especially in the era of the Ottoman government. In the Ottoman era in Turkey, waqf was a source of funding to the government as it provided for the people various facilities in education, healthcare and others. The al-Azhar waqf model in Egypt also benefited people in many aspects in education, so much so that every aspect of the management of al-Azhar University was funded from the waqf (Othman, 2015). This indicates that waqf is the best source of funding if it is managed in the best possible way.

Other than that, waqf is also the mechanism for asset and wealth distribution for individuals or even the country. In the Islamic economy, the redistribution of wealth is very much demanded for as it does not only contribute to the economic development of a country as it has the potential in creating a Madani community. According to Ab Rahman, (2009) the Islamic community is very close-knit and it is depicted as a building that is strong and formidable. She added that this kind of assistance is not in the form of energy alone but in the form of money and assets to seek for the blessings of Allah SWT. Thus, other than zakat and hibah, asset sharing can also be done through waqf for the sake of the wellbeing of mankind.

Waqf implementation in Muslim countries today has gained the attention of the society- be it traditional or contemporary implementation. This is shown through the existence of multiple instruments and facilities that motivate the people to donate or do waqf. Cash waqf, share waqf corporate waqf and so on give the opportunity to more and more people to do waqf especially on unfortunate ones and who cannot afford to donate permanent assets like land (Othman, 2015; Abdullah et al., 2020). Donating using the gold dinar ofr better known as waqf gold dinar (WDE) is also an instrument of waqf that has become the people's choice. (Hamid \& Mat Hassan, 2020; Hamid, 2018). Gold dinar has its own uniqueness and speciality as it has a permanent element that is consistent with the waqf concept (Othman 2015; Mat Hassan, 2015). Thus, waqf and gold dinar are the potential tools that can help construct a Madani community in a more comprehensive way.

Thus, this paper work elaborates on the concept of waqf gold dinar, the Madani community and further discusses the impact of the implementation of the WDE in the construction of a Madani community.

\section{Research Method}

This is a qualitative study involving the primary and secondary data collection. The primary data is obtained through face-to-face interview using semi-structured questions. The interview involved two informants. One is a waqf practitioner who is an officer at the State Islamic Council or MAIN in Malaysia- he has served for more than five years. Another is an active academician who conducts a study on waqf and gold dinar. To ensure that the 
information is confidential, the discussion in this study will be taking place, with the informants only labelled as IW 001 and IA 001 . The secondary data collection is carried out by analysing data from documents like books, journals, articles, magazines and so on. The collected data is analysed using the content analysis method based on the classification of themes that have been chosen with the help of the software Atlas t.i version 8 (AV8).

\section{The Study Analysis The Concept of Waqf Gold Dinar}

Gold dinar is a currency produced from gold originated from Rome. It is gold shilling produced and used in the territories of the Byzantium and Sasan Empires known as solidus. It was used even before Islam arrived which is in the era of the Lydia, Greek, Roman, also the Dark Ages governments right until the emergence of Islam in Medina known as gold dinar. Gold dinar is the Shari'a currency for Muslims (Yaacob et al., 2011; Mujani, 2012).

The gold dinar implied in this study is the pieces of gold produced according to the weight standard determined by the Caliph Umar Al-Khatab and applied in Malaysia today. This gold dinar is custom-made at the weight of 4.25 gram the weight of gold, and 22 carats where the difference in the weight and measurement is based on the relative weight of the gold money, which is "7 dinar equals to 10 dirham in weight" (Ismail, 2003).

There has been an extensive use of gold dinar in several countries, and they are South Africa (Cape Town), United Kingdom (Norwich), United Arab Emirates (Dubai), Indonesia and Malaysia. There are two methods of implementation of the gold dinar as practised in several countries and they are as currency (e-dinar electronic pay and zakat) and as commodity (savings, Hajj, gifts and dowry) (Yaacob et al., 2011; Mohammad, 2005; Amir Hassan, 2002; \& Muji Tahir, 2005). Mohammad (2005) also Yaacob and Muji Tahir (2005) also suggested that the use is made wider in matters related to acts of worship like zakat, hajj and dowry, not to mention waqf. This shows that gold dinar has the potential in building a Madani community for the good of mankind. Thus, it is reasonable to study the implementation of the gold dinar in the waqf system.

Waqf means 'refraining' (الحبس (al-Jurjani, 2004: 212; Ibn Manzur, t.t: 359). As a term, it means refraining from 'ain possessed by the donor (waqif) by donatign his or her assets. 'Ain of the asset will belong to Allah SWT in its entirety (al-Jurjani, t.t) and it is donated for $f i$ sabilillah (Mu'jam al-Wasit, t.t). According to Islamic scholars, waqf refers to a form of dedication be it discreetly (صارح) or subtly or in the form of cynicism (كناية) where the asset is withheld and the aim is directed for welfare or charity- general or specific (Al-Khin et al., (1998); Mahmud, 2007).

It can be concluded that waqf refers to any asset withheld by the donor from any buy-sell business, inheritance, hibah and will, other than retaining its physical source ('ain). The benefit is for general good or specific to get closer to Allah SWT. Thus, the asset is no longer the donor's and it can be taken back and cannot be owned by anyone else. The definition of waqf used in this paper work is waqf in which the asset or its 'ainis held and the return used for charity purposes. This is because that is the main criteria of waqf. 
The waqf asset developed has the potential to give contribution to the Muslims' socioeconomy especially in overcoming poverty. According to Othman (2011), poverty can be overcome through waqf if the assets are managed well by the parties responsible, namely MAIN (State Islamic Council), JAWHAR (Waqf, Haj and Zakat Department) and YWM (Malaysian Waqf Foundation). Apart from that, waqf also plays the role as a source of fund for Muslims' education for example to build a higher learning center, a school, to purchase learning equipment and tools, for scholarships and so on. This is evident through the implementation of al-Azhar waqf in Egypt where the return of the waqf is used to fund the management of the institution.

Based on the discussion about both waqf and gold dinar it can be summed up that the meaning of WDE is that waqf uses gold dinar without involving any use of paper money. The gold dinar is the asset donated (waqf) by the donor to the trustee or nazir. The WDE fund is then collected, and the invested and the outcome is used to but a permanent asset to be donated, which is called badal. The benefit of waqf gold dinar is that it will be used for charity and the ummah development, and further to produce a Madani community.

\section{The Concept of the Madani Community}

Madani community or also known as an ideal community life is very much talked about these days. However, how far it is understood by the general public, is still a question that lingers. It appears that although it has been mentioned quite frequently and the actual meaning introduced, people have yet to understand it in detail. Thus, briefly discusses the definition and characteristics of the Madani community.

The word Madani originates from the word "Madaniah" which means 'civilization'. In English, "civil" also refers to civilization or in other words, "Tamadun". The word 'Madani' is very much linked with the event of Muhammad and his followers' migration from the city of Mecca to Medina. It was from this event that a Madani community is produced, one that had experienced change from various aspects of life including the economy, religion, social and so on among the Muslim people from both cities. According to Hikam (1996) Madani community refers to a community or country that has a more systematic and proper social life.

A community has to have high elements of communality like democracy, tolerance, social justice and others. The Madani community is characterised as a community that has a social entity that lives together with the values that they practise collectively. A community has its own strength as is a country that comes from that community itself (Ibrahim, 2012). However, according to Ahmad Farouk (2011) to create democracy in the community, there must be a cooperation between the political parties and the leaders of the parties. If this happens, only then the democracy aspired will be materialised.

Based on the discussion, it can be concluded that the Madani community is one that is modernised in various aspects, including the mastery of the technology. The enforcement of the WDE is essential, to produce a quality Madani community not just in the worldly affairs but also in the Hereafter. This paper work proposes the WDE method of implementation towards the construction of the Madani community. 


\section{The Proposed Implementation of the waqf gold dinar Towards the Construction of the Madani community}

To get some in-depth information about the WDE implementation, we have interviewed 2 informants comprising of a waqf practitioner and an academician. Upon observation of the informants' views, generally they were unable to give a clear answer about the gold dinar method meant for waqf purposes. This is because the use of the gold dinar is still very new in the context of waqf today as seen by IW 001:

"I am confident, if we provide facilities for this, it can contribute in the form of gold value as the gold dinar has its own advantage, gold dinar is more stable compared to fiat money, but there will be a restriction to the mechanism. if we still want to do it, we need to have a mechanism that really makes it convenient for people to donate"

Based on the statement given by IW 001, he agreed that the use of gold dinar as a medium of waqf is a good suggestion. However, to realise its implementation, an effective method has to be devised. He added that, the method has to be convenient for people to do waqf. This is harmonious with the view of IA 001who suggested on the things that can be done and can be fixed.

From the view raised by IA 001, the existence of a community that can urge and influence the government to carry out WDE is pivotal. This method is one of the ways of motivating the government to act upon this. Based on this method, the community can form a small group or even a bigger group where this group is one that will ennoble gold dinar as a waqf mechanism. The group playing the role to urge and influence the government must have a strong relationship with the government. This is the statement made by IA 001, as follows:

"...if the one popularising is a certain group that does not have a strong relationship with the government, of course this will not be a hot issue, it will be delayed but it can be done, it can be comprehensive if the group that creates this discussion is the group that glorifies the gold dinar and they discuss with Bank Negara Malaysia, then Bank Negara Malaysia agrees.

Then, the group making it Malaysian, will leave a better impact"

Thus, it is important for the society to urge and influence some of the stakeholders in the country. These stakeholders will become the backbone to the emergence of the idea in empowering the WDE. If this is pushed by non-influential individuals or groups, this will be very hard to execute and time-consuming. Next, the idea's shift can be done by having a discussion with Bank Negara Malaysia where this idea stands as the main target. IA 001 reasserted his stand that a discussion is held with Bank Negara Malaysia, where he stated:

"...for me, the group that has conducted this, empowered the gold dinar must discuss with the Malaysian government especially Bank Negara Malaysia, which is the rightful party, as Bank Negara Malaysia has a lot of specific units"

With that, it is important for certain parties that have strength in terms of the number of members in an association or union to urge the government especially the Bank Negara Malaysia that the gold dinar is a very good alternative to replace the fiat cash in the waqf practice. Certain groups also have a very strong relationship with the government. Without this strong tie, like a loose dependency on the government, the use of gold dinar in waqf is very difficult to be done. 
IW 001 suggested that the R \& D cooperation between Group Research and the Parliament has to be established. This method also gives emphasis to certain parties who have a network with the authorities on the change of the laws in a country. Other than the society, academicians who also have their influence in politics are the group that is highly potential in motivating this. This is because it is very much associated with the R \& D Group Research and the parliament. Regarding this, IW 001 explained:

“...what is important is to conduct the R \& D Group Research, because normally, in Malaysia it will be brought to the parliament, and prior to this, parliament has its own researchers at various levels, and they need to make Malaysians, especially the sceptic to understand..."

This collaborative effort done between the researcher and the politicians is very important. This is because, researchers constitute an institution with members who are experts in academics, especially the knowledge discipline they study. Thus, those who are active in politics has an important role to play in changing something. On this premise, these $R$ \& $D$ Group Research groups serve as the major points of reference to ensure that the implementation can be achieved. Such an approach is considered appropriate to be used to leave an impact to the government policy and the formulation of new guideline to the society. The act of not collaborating with the authority is feared, would give a long-term effect to create something new, as explained by IW 001:

“...there is potential even if we don't work with the government, but it will be time-consuming if we work among us. For example, if it only the academic level that stresses on this, this will not give a great impact, other than circulating among the academicians only.."

The role of the experts or those who are carrying out the studies (research center) must be played by forging a good cooperation with the parliament members or the politicians. The measures that should be taken by the university be it a university body or one of the special units that examine in detail about the gold dinar as a waqf medium, should be handed to the politicians. They will then debate upon, and discuss, the findings obtained at the parliamentary level. During the discussion of the finding, the R \& D Research Group should be included in the discussion as the possibility for the politicians to know about the entire study in detail, would be slim. Thus, researchers play their part by explaining and answering all the questions that the parliament members have during the debate session. In this relation 001 had stressed:

"this has to be discussed consistently, frequently debated because when it is consistent, this will become a norm, and when it is a norm, people will naturally feel the need to change"

Other than participating in the discussion with the government, this also requires a frequent discussion or repeated debates. Because of this frequency, this has become a norm and it signals the importance of its implementation by the government. To carry out something new especially involving these inter-related issues, the way fiat money strongly depends on big authorities or parties, continuous efforts have to be made.

It also involves institutions that are both directly or indirectly linked with issues related to waqf for example the State Islamic Council (MAIN) and others. This is very much associated with the aspect of selection or the actual aim of the waqf system in Malaysia. The intention to get closer to Allah SWT and to get His blessings would normally be etched in the heart of a donor. However, the method in which the society is to be assisted is placed under the responsibility of MAIN. This is already dictated in the Malaysian legislative system. Thus, IA 
001 opined that this is not limited to MAIN only as waqf should be seen from the aspect of commercial entity like a business, and this was pointed out in his statement:

"...what has to be answered is that waqf is included in the banking system as it is characterized as business, or waqf only serves ana non-business entity, so if it is only under Council, then it is not a business"

What is meant by IA 001 is that, do we need to differentiate the business knowledge and waqf knowledge? His further statement is as follows:

"as for now, what has become a problem to me is that the issue of waqf is managed by the Islamic Council or department, they only know how to receive money but at the same time, everyone is saying that it must be traded, they are not professional because these people then also go into trade and they buy property"

From the statement given, the limited knowledge is among the factor as to why the waqf institutions in Malaysia are not growing exponentially as compared to those in other countries. He drew a comparison as such: "for example in Dubai that I went, waqf in Dubai is business, as it says in its slogan - Waqf Is Business". With this, it is important to make a choice whether the waqf implementation carried out has the aim to become an entity that is not commercial or has a commercial aim as intended. The institution responsible also has academic strength. These varying branches of knowledge should be put forth to introduce a waqf product as stated by IA001:

"...waqf must be maintained by professionals, their knowledge is economic-based

but religious knowledge cannot be neglected as it is very important."

Based on that, the emphasis on the participation of religious scholars is important when any discussion regarding waqf-related decisions is made. The absence of these religious experts will be indicative of the restrictions persistent in law determination. Matters related to the operations are placed in the hands of professionals in the fields of economy, business and social science in waqf administrative affairs. IA001 had stressed on this as he raised his opinion: "waqf comes from the religion, books or old scriptures so they are written and do have their own criteria", and he further added:

"...Islamic knowledge is very wide, so these modern knowledges such as administrative knowledge is included in Islam although it is not clearly mentioned, like if you are fated to receive waqf, the waqf must be managed and this is what administrative knowledge is all about"

Thus, both the groups must walk hand in hand together so that a new product can be created. The combination of both these sets of knowledge is essential, to make sure that the institution is well-managed not only in terms of the administration work but also in terms of the readiness with knowledge.

Based on the discussion in this section, it can be concluded that there are four important aspects that need to be established in the WDE implementation to build the Madani community. Firstly, there has to be a sense of urgency among the influential community members to influence the government to carry out WDE. Secondly, there should be a cooperation in R\&D between the research group and parliament members. Thirdly, there is a clear understanding among the institutions and the administrators of waqf assets. Fourthly, there should be a combined professional and religious knowledge to ensure that the implementation is in line with the shari'a and the waqf concept itself. The summary of the method of implementation of the WDE is depicted in Diagram 1. 
Diagram 1 portrays the method of implementation of WDE that starts with the urgency from an influential community. This is continued by the R\&D collaboration between Research Group and the Parliament. It involves the implementation by the waqf institutions like MAIN that combine the religious and the professional groups.

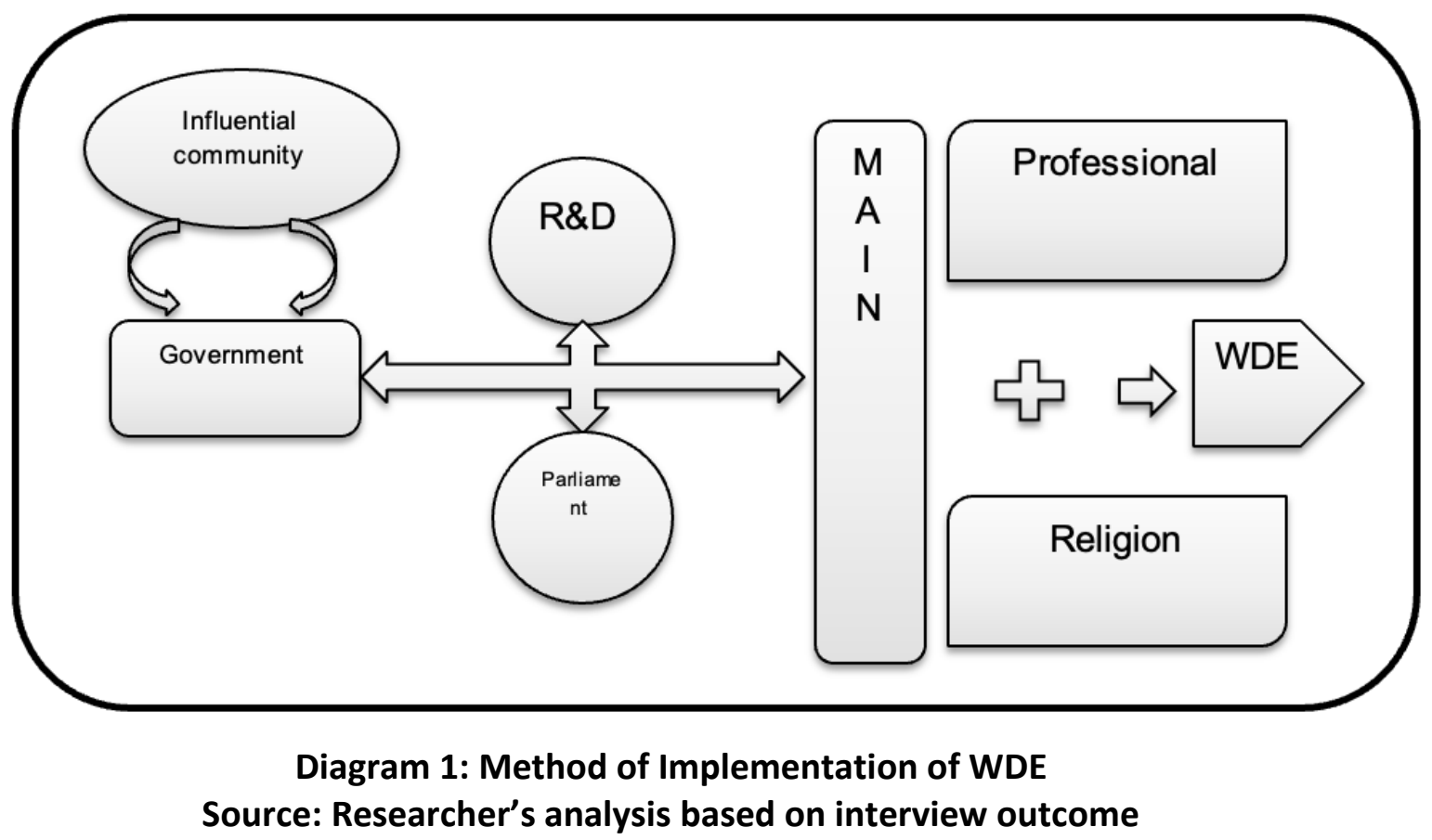

With the WDE implemented, the construction of the Madani community can be realised. This goes consistently with the characteristics of the Madani community that tolerates with one another. The community is always helping one another irrespective of religion, nation and culture. This is consistent with the concept of waqf where the benefit from the waqf asset must be continued and can be benefited by every layer of the community. Other than that, the social justice can also be created because the recipients are not discriminated against by their religion and race. This is proof that the implementation of WDE has the potential to produce the Madani community the way it happened in the early era of Islamic Civilization.

\section{Conclusion}

Conclusively, gold dinar is a shari'a currency that has its own distinctive feature. Its impact of implementation as a waqf instrument has been very positive as we look into the ummah development and the formation of Madani community. An effective enforcement of WDE encompasses four main aspects, namely the urge from the community who has its own influence on the government, the R\&D collaboration with the parliament members, the understanding of the waqf administrators and the knowledge affiliation between the religious officers and the professionals. With these elements, the WDE is able to realise the development of the Madani community.

\section{References}

Ab Rahman, A. (2009). Peranan wakaf dalam pembangunan ekonomi umat Islam. Jurnal Syariah, 17, 1, 113-152.

Abdullah, S. R, Mat Hassan, S. H., Fazial, F., Yahya, S., \& Hamid, C. K. (2020). Pelaksanaan kaedah pembiayaan secara langsung dalam pembangunan harta wakaf di Malaysia. 
Proceeding International Conference of Contemporary Issue in Islamic Finance (eICCIF2020)

Farouk, A. F. (2011). The limits of civil society in democratising the state: The Malaysian case. Kajian Malaysia, 29(1), 91-109.

Hassan, A. U. A (2002). Penggunaan mata wang dinar dalam era globalisasi, kertas kerja yang dibentangkan di Seminar Dinar Peringkat Kebangsaan, anjuran Kolej Universiti Islam Malaysia (KUIM), Kuala Lumpur pada 16 Mac 2002.

Al-Khin, M., Al-Bugho, M., \& Asy-Syarbaji, A. (1998). Kitab Fikah Mazhab Syafie (Jilid: 5): Menghuraikan bab wakaf, wasiat dan faraid. Kuala Lumpur: Pustaka Salam.

Hamid, C. K., \& Mat Hassan, S. H. (2020). Kaedah Pelaksanaan Dinar Emas Sebagai Instrumen Wakaf. Jurnal Borneo Akademika. 4 (2), 53 - 63.

Hikam, M. A. S. (1996). Demokrasi dan Civil Soceity. Jakarta: LPES.

Ibrahim, F. W. (2012). Pembentukan Masyarakat Madani Di Indonesia Melalui Civic Education. Jurnal IImiah DIDAKTIKA, XIII (1), 130-149.

Mahamod, S. M. (2007). Pembentukan dana wakaf menurut perspektif syariah dan undangundang serta aplikasinya di Malaysia, Jurnal Syariah, 15, 2: 61-83.

Mohamad, N. M. (2005). The real implementation of the gold dinar economy, kerta kerja persidangan yang diakses dari http:www.islam.gov.my/muamalat/kertas persidangan.

Mat Hassan, S. H. (2015). Potensi dinar emas dalam wakaf tunai. Kuala Lumpur: Dewan Bahasa dan Pustaka (DBP).

Mujani, W. K. (2012). Sejarah dinar: Dari zaman pra Islam sehingga zaman Uthmani. Bangi: Institut Kajian Rantau Asia Barat (IKRAB), UKM.

Othman, R. (2015). Wakaf Tunai: Sejarah, Amalan Dan Cabaran Masa Kini. Kuala Lumpur: Dewan Bahasa dan Pustaka (DBP).

Othman, R. (2011). Pembasmian kemiskinan: Peranan dan sumbangan institusi wakaf. Pengurusan Ilmu, Ekonomi dan Pembangunan Berteraskan Islam. Pulau Pinang: Penerbitan Universiti Sains Malaysia (USM).

Yaacob, S. E., \& Tahir, M. H. (2010). Realiti Semasa Penggunaan Dinar Emas Di Malaysia. Diakses dari http://www.islam.gov.my/muamalat

Yaacob, S. E., Samuri, M. A. A., Kashim, M. I. A. M., Jamsari, E. A., \& Ashari, M. Z. A. H. (2011). Dinar Emas Sebagai Mata Wang Dan Komoditi Di Beberapa Negara Terpilih (Gold Dinar As A Currency And Commodity In Selected Countries). Jurnal Melayu, 7.

Ismail, Z. (2003). Kembalinya dinar Emas dan dirham perak: Mata wang umat Islam. Skudai, Johor: UTM. 